\section{Bangladesh sets up institute of nuclear agriculture}

THE Vice-President of the Bangladesh Republic officially inaugurated the Institute of Nuclear Agriculture (INA) last month. This Institute, set up in collaboration with the International Atomic Energy Agency (IAEA), is the fourth large one of this kind to be built. The others are in Yugoslavia, India and Brazil. The Institute has been established in the premises of Bangladesh Agricultural University with the objective of identifying and solving the basic agricultural problems of the country through interdisciplinary approaches employing both nuclear and conventional techniques.

Agriculture is the mainstay of the Bangladesh economy. Farm products alone account for about $55 \%$ of the Gross Domestic Product (GDP), so the importance of boosting productivity can hardly be over-emphasised at a time when the country is facing the joint problems of food shortage and a fast growing population.

The initial research programmes of the Institute are in plant physiology, plant genetics, soil science, and entoagriculture. mology, with emphasis on improving varieties of rice, jute, wheat, pulses, tomato and oil seeds. INA has already achieved some encouraging results in evolving new rice varieties, such as IRRATOM-24 and IRRATOM-38 through irradiation technique. They are capable of higher yield and early maturing than mother variety IRRI-8. Similarly, the two new strains of jute known as ATOMPAT-8 and ATOMPAT-38 have been found superior to the mother, D-154.

Mr Hellio F. S. Bittencourt, Deputy Director General of IAEA, addressing the inaugural ceremony said that the application of nuclear techniques in agricultural research was by no means a luxury for the developing countries; it was the base proven method for solving certain practical problems of

The Swedish International Development Agency (SIDA) has provided a grant of over one million US dollars towards the cost of equipment, advisory service and fellowships, IAEA being the executant agency.

M. Kabir

\section{Less paper, more money for US scientists}

DR Frank Press, director of the US Office of Science and Technology Policy, has launched a major campaign to encourage Government agencies to reduce the amount of time that university scientists receiving federal suppont are required to spend on paperwork.

Speaking in Washington last week, Dr Press said that the money that could be saved in this way might amount to millions of dollars for every university.

"One of the goals of this administration is to make universities perform better the basic research which the government subsidises. One way of reducing paperwork and overheads, for example, would be to award longerterm grants, so that scientists do not have to be writing new research proposals every three months or so."

Dr Press said that the Department of Health, Education and Welfare, which is responsible for the research carried out by the Nation'al Institutes of Health, is already looking at ways in which it can help universities by reducing paperwork and streamlining regulations about grants.

"I have also written to NASA (the National Aeronautic and Space Administration) and to NSF (the National Science Foundation) asking them what their plans are on this," he said.

\section{The facts about Kosmos-954}

RECOVERY of the fragments of Kosmos-954 is proving, not surprisingly, a lengthy operation, and although some sizeable pieces have apparently been located and taken for examination to White Shell, Manitoba, it may be some considerable time before any hard facts are available about the type of satellite and reactor actually involved. Although the figure of $50 \mathrm{~kg}$ U-235 has been tossed around fairly freely, this is simply an assumption the reactor involved was of Romashka type. This is the only Soviet reactor of comparable type ever described in open publications; accordingly, it is the only basis for speculation. The Romashka has a $40 \mathrm{~kW}$ thermal yield and was, indeed, designed for space use, and assuming that such reactors are still used aboard certain Soviet satellites, it is possible to work out tentative figures for radiation hazards for this, and possible future, satellite crashes.

Three scenarios have been discussed among the experts. The first-break-up of the satellite in the stratosphererequires the use of additional data. This comes from the US Navy SNAP$9 \mathrm{~A}$, powered by a plutonium source, which disintegrated before entry into orbit in 1964. On this basis, assuming an initial charge of $50 \mathrm{~kg} \mathrm{U}-235$ - and 100 days in orbit before disaster, one arrives at the comforting figure that six months after the incident the residual radioactivity would be of the order of $10^{-9}$ of the International Commission for Radiological Protection safety level. (This is the concentration of airborne radioactivity that could be breathed 24 hours a day without harm.)

For break-up on impact, the downwind distance to which the UK Medical Research Council emergency reference levels extend works out at the order of a few $\mathrm{km}$. (This means in effect that beyond this distance the hazards of mass evacuation are considered to be greater than the risk from radiation). For impact in one piece, if no chain reaction occurred, initial radiation levels would be expected of $1 \mathrm{rad} / \mathrm{h}$ at $200 \mathrm{~m}$ from the site, 100 millirad at $500 \mathrm{~m}, 10 \mathrm{millirad}$ at $1500 \mathrm{~m}$. Had the impact occurred in a populous area, evacuation would have been necessary up to $2 \mathrm{~km}$, if no intervening shielding (e.g. masonry) were present. Chain reaction is unlikely, since the mass of uranium used in such satellites is normally subcritical, and special methods, e.g. a reflector, must be used to keep sufficient neutrons within it to maintain a chain reaction. Such a reflector would virtually certainly become 